\title{
PENGARUH MOTIVASI BONUS, MOTIVASI KONTRAK HUTANG, MOTIVASI POLITIK DAN KUALITAS AUDIT TERHADAP MANAJEMEN LABA (STUDI EMPIRIS PADA PERUSAHAAN BUMN YANG TERDAFTAR DI BURSA EFEK INDONESIA)
}

\author{
Nawang Kalbuana', Titik Purwanti ${ }^{2}$, Ayu Setiani Mayzaroh ${ }^{3}$ \\ Politektik Penerbangan Indonesia Curug, Unwidha Klaten, ITB Ahmad Dahlan \\ E-mail: ${ }^{1}$ nawang.kalbuana@stpicurug.ac.id, ${ }^{2}$ titik@unwidha.ac.id, ${ }^{3}$ setianiayu21@gmail.com
}

\begin{abstract}
Abstrak : Penelitian ini bertujuan untuk menganalisis pengaruh motivasi dan kualitas audit terhadap manajemen laba pada perusahaan bumn di indonesia. Penelitian ini merupakan penelitian kuantitatif, dengan manajemen laba sebagai variabel dependen. Manajemen laba diukur dengan menggunakan discretionary accruals (da) yang dihitung dengan menggunakan modified jones model. Variabel independen yang diteliti antara lain motivasi bonus, motivasi kontrak dan kualitas audit. Sampel dari penelitian ini adalah perusahaan bumn yang terdaftar di bursa efek indonesia pada tahun 2013-2017. Sampel dipilih dengan metode purposive sampling. Analisis data dilakukan dengan uji asumsi klasik dan pengujian hipotesis dengan metode regresi linier berganda. Hasil dari penelitian ini menunjukkan bahwa motivasi kontrak dan kualitas audit berpengaruh signifikan terhadap manajemen laba, sedangkan motivasi bonus tidak berpengaruh terhadap penghindaran manajemen laba.
\end{abstract}

Kata Kunci: motivasi bonus, motivasi kontrak hutang , motivasi politik, kualitas audit dan manajemen laba.

Abstract : This study aims to analyze the effect of motivation and audit quality on earnings management in state-owned companies in indonesia. This research is a quantitative study, with earnings management as the dependent variable. Earnings management is measured using discretionary accruals (da) which are calculated using the modified jones model. The independent variables studied were bonus motivation, contract motivation and audit quality. The sample of this research is a state-owned company listed on the indonesia stock exchange in 2013-2017. Samples were selected by purposive sampling method. Data analysis was performed with the classical assumption test and hypothesis testing with multiple linear regression methods. The results of this study indicate that contract motivation and audit quality have a significant effect on profit management, while bonus motivation has no effect on profit management avoidance.

Keywords: bonus motivation, contract motivation, politic motivation, audit quality, and earnings management..

\section{PENDAHULUAN}

Kinerja manajemen perusahaan tercermin pada laba yang terkandung dalam laporan keuangan, sehingga informasi laba merupakan informasi yang penting sebagai dasar pengambilan keputusan investasi. Informasi laba ini sering menjadi target rekayasa tindakan oportunis manajemen untuk memaksimalkan kepentingannya, sehingga dapat merugikan investor. Perilaku mengatur laba perusahaan sesuai dengan keinginan manajemen ini dikenal dengan istilah manajemen laba (earnings management).

Manajemen laba timbul sebagai dampak persoalan keagenan yaitu ketidakselarasan kepentingan antara manajer dan pemilik perusahaan yang dikarenakan adanya asimetri 
informasi. Asimetri informasi adalah suatu kondisi dimanaadanya ketidakseimbangan dalam perolehan informasi antara manajemen dan pemegang saham dimana manajemen memiliki informasi yang lebih dibanding dengan pihak eksternal (Christiani, Nugrahanti., 2014).

Aryani (2011) menyatakan bahwa kesenjangan motivasi yang mendasari manajer tergantung pada pengungkapan informasi tertentu terkait manfaat yang diperolehnya. Manajer tidak selalu membuat informasi menjadi lebih bagus dibandingkan dengan informasi sesungguhnya (income increasing), sebaliknya manajer ada kalanya membuat informasi menjadi lebih buruk bila dibandingkan informasi sesungguhnya (income decreasing) Ulupui (2014). Hal ini mengindikasikan bahwa pihak manajer memiliki kesempatan yang besar untuk menentukan besarnya laba pada suatu periode dan laba pada periode yang akan datang dengan cara mempercepat atau memperlambat proses pengakuan beban ataupun pengakuan keuntungan.

Selain penggunaan kebijakan akrual, manajemen laba juga bisa dilakukan melalui dasar kas (riil). Manipulasi laba tersebut dinamakan manajemen laba rill (Roychowdhury, 2006; Cohen, 2008). Beberapa aktivitas manipulasi riil dilakukan dengan cara pemberian diskon penjualan secara besar-besaran, peningkatan produksi secara berlebihan sehingga mengurangi biaya produksi, pemotongan anggaran diskresioner seperti pengeluaran iklan, penelitian dan pengembangan, pelatihan karyawan. Manajemen laba riil sulit untuk dideteksi secara langsung oleh auditor maupun pengguna laporan keuangan, sehingga dampak kerugian adanya manajemen laba rill pada kinerja perusahaan jangka panjang lebih besar dibanding manajemen laba akrual.

Secara umum terdapat beberapa hal yang dapat memotivasi individu atau badan usaha melakukan tindakan manajemen laba, yaitu karena adanya motivasi bonus, motivasi utang/kontrak, motivasi pajak, Motivasi Initial Public Offering (IPO), Motivasi Pergantian Direksi, Motivasi Politis. Sesuai dengan perumusan masalah diatas, tujuan penelitian ini adalah untuk memperoleh bukti empiris tentang pengaruh motivasi bonus, motivasi kontrak, motivasi politik dan kualitas audit terhadap manajemen laba pada perusahaan BUMN yang terdaftar di Bursa Efek Indonesia.

\section{LANDASAN TEORI}

\subsection{Teori Agensi}

Teori Agensi menyatakan hubungan kontrak antara agen (manajemen suatu usaha) dan prinsipal (pemilik usaha). Agen melakukan tugas-tugas tertentu untuk prinsipal, prinsipal mempunyai kewajiban untuk memberi imbalan pada si agen. (Jensen dan Meckling, 1976) menyatakan bahwa hubungan keagenan sebagai kontrak antara satu atau beberapa orang (pemberi kerja atau prinsipal) yang mempekerjakan orang lain (agen) untuk melakukan sejumlah jasa dan memberikan wewenang dalam pengambilan keputusan. Terdapat perbedaan kepentingan antara para pihak, satu sisi manajer menginginkan peningkatan kompensasi, pemegang saham ingin menekan biaya pajak, kreditur menginginkan perusahaan dapat memenuhi kontrak utang dan membayar bunga, pokok utang tepat waktu. (Marsi dan Martani, 2012).

\subsection{Manajemen Laba}

Setiawati dan Na'im (2000) mendefinisikan manajemen laba adalah campur tangan manajemen dalam proses pelaporan keuangan eksternal dengantujuan untuk menguntungkan dirinya sendiri. Manajemen laba merupakan satu faktor yang dapat mengurangi kredibilitas laporan keuangan. Manajemen laba menambah bias dalam laporan keuangan dan dapat menggangu pemakai laporan keuangan yang mempercayai angka laba hasil rekayasa tersebut sebagai angka laba tanpa rekayasa. 
Manajemen laba dapat terjadi karena dalam penyusunan laporan keuangan menggunakan basis akrual.Akuntansi berbasis akrual menggunakan prosedur akrual, deferral, pengalokasian yang bertujuan untuk menghubungkan pendapatan, biaya, keuntungan (gains), dan kerugian (losses) untuk menggambarkan kinerja perusahaan selama periode berjalan, meski kas belum diterima dan dikeluarkan (Sulistyanto, 2008).Salah satu teknik mengukur tinglat manajemen laba karual dengan menggunakan nilai Discretionary Accruals (DA).

Variabel Manajemen Laba Akrual diukur dengan menggunakan Discretionary Accruals (DA) yang dihitung dengan cara Modified Jones Model. Nilai DA diukur dengan menggunakan rumus sebagai berikut :

TAC $=$ Net Income- Cash Flow from Operation

Keterangan ;

$\mathrm{TAC}=$ Total Accrual

Perhitungan untuk Nondiscretionary Accrual (NDA) menurut model Jones yang dimodifikasi dirumuskan sebagai berikut:

$\operatorname{NDA}_{t}=\alpha 1\left(1 / A_{t-1}\right)+\alpha 2\left(\Delta R V_{t}-\Delta R E C_{t} / A_{t-1}\right)+\alpha 3\left(P P E_{t} / A_{t-1}\right)$

Keterangan:

NDAt $=$ non discretionary accrual perusahaan i pada Keterangan ;

NDAt $=$ non discretionary accrual perusahaan i pada tahun $t$

At-1 $=$ total aset perusahaan i pada tahun $\mathrm{t}-1$

$\triangle \mathrm{REVt}=$ pendapatan perusahaan i pada tahun 1 dikurangi pendapatan i-1

$\triangle \mathrm{RECt}=$ perubahan piutang perusahaan i dari tahun $\mathrm{t}-1$ ke tahun $\mathrm{t}$

$\mathrm{PPEt}=$ aset tetap perusahaan $\mathrm{i}$ pada tahun $\mathrm{t}$

Dari persamaan-persamaan diatas, akrual dikresioner dapat dihitung dengan rumus :

$$
\operatorname{DAC}_{t}=\left(\text { TAC }_{t} / A_{t-1}\right) . N-A_{t}
$$

Keterangan ;

$\mathrm{DACt}=$ discretionary accruals perusahaan i pada tahun $\mathrm{t}$

$\mathrm{TACt}=$ total accrual perusahaan i pada tahun $\mathrm{t}$

At-1 = total aset perusahaan i pada tahun $\mathrm{t}-1$

$\mathrm{NDAt}=$ non discretionary accrual perusahaan $\mathrm{i}$ pada tahun $\mathrm{t}$

\subsection{Motivasi Bonus}

Manajemen akan memilih metode akuntansi yang memaksimalkan utilitasnya yaitu bonus yang tinggi. Manager perusahaan yang memberikan bonus terbesar berdasarkan laba lebih banyak menggunakan metode akuntansi yang meningkatkan laba untuk dilaporkan. Dalam kontrak bonus dikenal dua istilah yaitu tingkat laba terendah dan tingkat laba tertinggi untuk mendapatkan bonus. Jika laba beradadi bawah tingkat laba terendah, manajer cenderung memperkecil laba dengan harapan memperoleh bonus lebih besar pada periode berikutnya, begitu pula sebaliknya. Jadi manajer hanya akan menaikan laba jika laba bersih 
berada diantara tingkat laba terendah dan tingkat laba tertinggi (Syahrial, 2013). Motivasi Bonus diukur dengan menggunakan rasio Return On Assets (ROA). ROA marupakan kemampuan perusahaan untuk menghasilkan keuntungan yang diperoleh berdasarkan total asset perusahaan ROA dapat dirumuskan sebagai berikut:

\section{ROA $=$ Earning Before Interest and Taxes}

Total Aset

H1: Motivasi bonus mempunyai pengaruh signifikan terhadap manajemen laba.

\subsection{Motivasi kontrak Hutang}

Pinjaman merupakan modal yang diperoleh dari pihak eksternal dari kreditor. Manajer harus menunjukkan performa yang baik dari perusahaannya dalam rangka upaya manajer dalam menarik kreditor agar kreditor mau menginvestasikan dananya ke perusahaan (Sulistiawan et al. 2011, 32 dalam Hadidi Sutrisno, 2017). Hasil dari upaya manajer dalam rangka menarik kreditor untu mendapat pinjaman dan pinjaman yang dilakukan oleh perusahaan tentu menuntut pertanggungjawaban perusahaan. Pihak kreditor akan selalu memantau dan mengawasi mengenai keadaan perusahaan.

Motivasi kontrak utang merupakan motivasi manajer dalam mengelola dan mengatur labanya agar kewajiban hutang perusahaan yang seharusnya diselesaikan pada tahun tertentu dapat ditunda untuk tahun berikutnya. Motivasi kontrak utang diukur dengan menggunakan rasio leverage. Pengukuran yang digunakan adalah sesuai dengan Nurdiniah dan Herlina (2013) dalam Hadidi dan Sutrisno (2017) yang menggunakan motivasi kontrak utang dengan rumus debt to total asset.

\section{LEV $=($ Total Liabilitas $) /($ Total Assets $)$}

H2: Motivasi kontrak hutang mempunyai pengaruh signifikan terhadap manajemen laba.

\subsection{Motivasi Biaya Politik}

Motivasi biaya politik diukur dengan mengunakan cerminan nilai yang menunjukkan besar kecilnya suatu perusahaan yang terlihat dari ukuran perusahaan. Ukuran perusahaan merupakan skala ukuran perusahaan sehingga perusahaan besar dan kecil dapat diklasifikasikan (Nurdiniah dan Herlina, 2015). Perusahaan yang berukuran besar biasanya memiliki tingkat penjualan lebih besar, kepentingan yang luas terhadap publik dan tingkat kestabilan perusahaan lebih tinggi yang melibatkan lebih banyak pihak.

Perusahaan besar berpengaruh terhadap publik dalam tindakan pengambilan keputusan, sehingga masyarakat lebih mengenal atau mengetahui perusahaan besar dibandingkan perusahaan kecil (Zeptian dan Rohman, 2013). Lee and Choi (2002) dalam Siregar dan utama (2005) menemukan bahwa ukuran perusahaan dipandang lebih kritis oleh pihak luar karena diduga mempengaruhi besaran pengelolaan laba.

Motivasi biaya politik diukur dengan menggunakan ukuran perusahaan sehingga antara perusahaan besar dan kecil dapat diklasifikasikan. Pengukurannya menggunakan penelitian Nurdiniah dan Herlina (2013) dalam Hadidi dan Sutrisno (2017) yang memakai logaritma natural dari total aset perusahaan.

\section{$\mathrm{Up}=\mathrm{Ln}$ (Total Asset Perusahaan)}

H3: Motivasi biaya politik mempunyai pengaruh signifikan terhadap manajemen laba. 


\subsection{Kualitas Auditor}

Meutia (2004) dalam Christiani dan Nugrahanti (2014) mendefinisikan audit sebagai suatu proses untuk mengurangi ketidakselarasan informasi yang terdapat antara manajer dan para pemegang saham dengan menggunakan pihak luar untuk memberikan pengesahan terhadap laporan keuangan.

DeAngelo (1981) mendefinisikan kualitas audit sebagai probabilitas gabungan untuk mendeteksi dan melaporkan kesalahan yang material dalam laporan keuangan. Kualitas audit dipandang sebagai kemampuan untuk mempertinggi kualitas pelaporan keuangan perusahaan. Dengan kualitas audit yang tinggi diharapkan mampu meningkatkan kepercayaan investor. Kualitas audit diproksikan dengan dua variabel yaitu ukuran KAP. Kualitas Auditor dikukur dengan variable Dummy. Pengukuran dilakukan dengan memberi nilai 1 jika perusahaan diaudit oleh KAP Big4 (Deloitte, PWC, KPMG, dan E\&Y) dan memberi nilai 0 jika diaudit oleh KAP Non Big4.

H4: Kualitas Audit mempunyai pengaruh signifikan terhadap manajemen laba.

\subsection{Penelitian Terdahulu}

Penelitian ini juga mengadaptasi dari beberapa penelitian sebelumnya yang masih berkaitan yaitu sebagai berikut:

\begin{tabular}{|c|c|c|}
\hline Peneliti & Judul Penelitian & Hasil Penelitian \\
\hline $\begin{array}{l}\text { Novia Fitri Kusumawardani } \\
\text { R. Rosiyana Dewi }\end{array}$ & $\begin{array}{l}\text { Motivasi bonus, pajak, } \\
\text { dan utang dalam } \\
\text { tindakan manajemen } \\
\text { laba (studi perusahaan } \\
\text { manufaktur yang } \\
\text { terdaftar di bursa efek } \\
\text { indonesia) }\end{array}$ & $\begin{array}{l}\text { Variabel bonus berpengaruh signifikan positif } \\
\text { terhadap variabel manajemen } \\
\text { laba. Variabel pajak berpengaruh signifikan } \\
\text { positif terhadap variabel manajemen laba. } \\
\text { Variabel utang berpengaruh signifikan positif } \\
\text { terhadap variabel manajemen laba. }\end{array}$ \\
\hline Riza Ramadhan & $\begin{array}{l}\text { Analisis faktor yang } \\
\text { mempengaruhi } \\
\text { manajemen laba pada } \\
\text { perusahaan manufaktur } \\
\text { yang tercatat di BEI }\end{array}$ & $\begin{array}{l}\text { Motivasi bonus, Kontrak hutang dan ukuran } \\
\text { perusahaan tidak berpengaruh terhadap } \\
\text { manajemen laba }\end{array}$ \\
\hline $\begin{array}{l}\text { Andreani Caroline Barus, } \\
\text { Yosephine Natalita } \\
\text { Sembiring }\end{array}$ & $\begin{array}{l}\text { Faktor-faktor yang } \\
\text { mempengaruhi } \\
\text { motivasi manajemen } \\
\text { laba di seputar right } \\
\text { issue }\end{array}$ & $\begin{array}{l}\text { Variabel leverage } \\
\text { yang menunjukkan hasil yang signifikan } \\
\text { positif, Kepemilikan Institusi dan Manajerial } \\
\text { tidak berpengaruh terhadap manajemen laba. }\end{array}$ \\
\hline
\end{tabular}

\section{METODOLOGI PENELITIAN}

a. Populasi dan Sampel

Populasi dalam penelitian ini adalah perusahaan BUMN yang terdaftar di Bursa Efek Indonesia (BEI) selama periode 2013-2017. Pada penelitian ini teknik pengambilan sampel menggunakan metode non probability sampling dengan teknik purposive sampling dengan pertimbangan sebagai berikut: (1) Perusahaan BUMN yang terdaftar di Bursa Efek Indonesia (BEI) selama periode 2013 - 2017. (2) Perusahaan yang terdaftar di BEI dan laporan keuangannya sudah diaudit oleh akuntan publik. (3) Perusahaan yang laporan keuangannya menggunakan satuan mata uang Rupiah dan memiliki laba bersih yang positif.

b. Jenis dan Sumber Data

Jenis data yang digunakan dalam penelitian ini adalah data sekunder. Data sekunder yang dibutuhkan dalam penelitian ini adalah laporan keuangan perusahaan yang telah 
diaudit pada tahun 2013-2017 pada perusahaan publik yang terdaftar di Bursa Efek Indonesia. Data sekunder yang dikumpulkan diperoleh melalui website www.idx.co.id.

c. Variabel Penelitian

Berdasarkan pokok permasalahan yang telah dirumuskan di atas, maka Variabel dependen dalam penelitian ini adalah manajemen laba. Model estimasi pengukuran diukur dengan menggunakan Discretionary Accruals (DA) yang dihitung dengan cara Modified Jones Model.

Variabel independen dalam penelitian ini adalah motivasi bonus, motivasi kontrak hutang, motivasi politik, kualitas audit.

\section{PEMBAHASAN}

Penelitian ini menggunakan perusahaan BUMN yang terdaftar di Bursa Efek Indonesia pada tahun 2013-2017. Berdasarkan purposive sampling, didapatkan 13 perusahaan BUMN yang dijadikan sampel. Dengan jumlah tahun penelitian adalah 5 tahun (2013-2017), maka total data penelitian adalah 65 data.

\subsection{Statistik Deskriptif}

Dari hasil statistik deskriptif pada tabel 1, dapat diperoleh gambaran dari masingmasing variabel dari model penelitian ini. Manajemen laba memiliki nilai terendah sebesar 0.18 dan nilai tertinggi sebesar 1012.90 serta nilai rata-rata sebesar 77.9511. Pada variable Motivasi Bonus nilai terendah sebesar 0.00 dan nilai tertinggi 0.0542 serta nilai rata-rata 0.28. Selanjutnya variabel Motivasi Kontrak Utang memiliki nilai terendah sebesar 0,00 dan nilai tertinggi 0.5517 serta memiliki nikai rata-rata 0.92. Selanjutnya pada variable Motivasi Biaya Politik memiliki nilai terendah sebesar 23.81 dan nilai tertinggi 30.4280 serta nilai rata-rata 34.66. Selanjutnya variabel Kualitas Audit nilai terendah sebesar 0,00 dan nilai tertinggi 0.5231 serta memiliki nikai rata-rata 1.00 .

\subsection{Regresi Linear Berganda}

Berdasarkan Tabel 2. bagian Coefficients tersebut pada lampiran, maka dapat dibuat model regresi linier berganda dengan persamaan sebagai berikut:

$\mathrm{Y}=\mathbf{2 2 8 5 , 9 2 3}-\mathbf{5 5 9 , 5 4 5} \mathrm{X} 1+\mathbf{2 0 1 , 0 0 4} \mathrm{X} 2-\mathbf{7 8 , 1 8 0 X 3}+\mathbf{1 7 2 , 5 7 1} \mathrm{X} 4+\mathrm{E}$

\subsection{Uji Asumsi Klasik}

Berdasarkan hasil uji multikolinieritas pada tabel 2, menunjukkan bahwa berdasarkan hasil pengujian tersebut, tidak ada satupun variabel bebas (variabel independen) yang memiliki nilai tolerance dibawah 0,10 dan nilai VIF diatas 10. Sehingga dapat disimpulkan bahwa tidak terjadi multikolinieritas antar variabel bebas di dalam model regresi.

\subsection{Uji Parsial (Uji T)}

Berdasarkan hasil perhitungan pada tabel 3 dijelaskan bahwa:

a. Pengaruh motivasi bonus terhadap manajemen laba dapat dilihat pada besarnya signifikansi yang menunjukkan nilai sebesar 0.095. Nilai signifikan sebesar 0.095 lebih besar dari 0,05 yang berarti Hal ditolak. Dengan demikian dapat dinyatakan bahwa Motivasi Bonus tidak berpengaruh signifikan terhadap manajemen laba.

b. Pengaruh motivasi kontrak hutang terhadap manajemen laba dapat dilihat pada besarnya signifikansi yang menunjukkan nilai sebesar 0.015. Nilai signifikan sebesar 0.015 lebih kecil dari 0,05 yang berarti Ha2 diterima. Dengan demikian dapat dinyatakan bahwa Motivasi Kontrak Hutang berpengaruh signifikan terhadap manajemen laba. 
c. Pengaruh motivasi politik terhadap manajemen laba dapat dilihat pada besarnya signifikansi yang menunjukkan nilai sebesar 0.000. Nilai signifikan sebesar 0.000 lebih kecil dari 0,05 yang berarti Ha3 diterima. Dengan demikian dapat dinyatakan bahwa Motivasi Politik berpengaruh signifikan terhadap manajemen laba.

d. Pengaruh kualitas audit terhadap manajemen laba dapat dilihat pada besarnya signifikansi yang menunjukkan nilai sebesar 0.000. Nilai signifikan sebesar 0.000 lebih kecil dari 0,05 yang berarti Ha4 diterima. Dengan demikian dapat dinyatakan bahwa Kualitas Audit berpengaruh signifikan terhadap manajemen laba.

\subsection{Uji Simultan (Uji F)}

Berdasarkan hasil perhitungan terlihat pada tabel 4, diperoleh nilai signifikansi sebesar $0,000<0,05$; artinya secara bersama-sama variabel X1, X2,X3 dan X4 berpengaruh signifikan terhadap manajemen laba. Sehingga pemilihan variabel Motovasi Bonus, Motivasi Kontrak Utang, Motivasi Biaya Politik Dan Kualitas Audit sebagai prediktor dari manajemen laba pada perusahaan sektor BUMN di Bursa Efek Indonesia sudah tepat.

\subsection{Koefisien Determinasi}

a. Dari hasil perhitungan pada tabel 5, Koefisien Determinasi (Adjustend $R$ Square) sebesar 0,662 atau sebesar 66,2\% yang berarti bahwa kemampuan Variabel X1, X2, X3 dan X4 dalam menjelaskan Variabel Y, adalah sebesar 66,2\%. Sedang sisanya sebesar $33,8 \%$ dijelaskan oleh variabel lain diluar dari variabel penelitian ini.

b. Nilai R sebesar 0,827 memiliki arti bahwa korelasi bergandanya adalah tinggi..

\section{KESIMPULAN}

Berdasarkan hasil penelitian tentang pengaruh motivasi bonus, motivasi kontrak hutang , motivasi politik, kualitas audit pada perusahaan BUMN yang terdaftar di Bursa Efek Indonesia selama periode 2013-2017 sebagai berikut:

a. Motivasi bonus tidak berpengaruh signifikan terhadap manajemen laba pada perusahaan BUMN yang terdaftar di Bursa Efek Indonesia, sehingga H1 ditolak kebenarannya.

b. Motivasi kontrak hutang berpengaruh signifikan terhadap manajemen laba pada perusahaan BUMN yang terdaftar di Bursa Efek Indonesia, sehingga $\mathrm{H} 2$ diterima kebenarannya.

c. Motivasi politik berpengaruh signifikan terhadap manajemen laba pada perusahaan BUMN yang terdaftar di Bursa Efek Indonesia, sehingga H3 diterima kebenarannya.

d. Motivasi kualitas audit berpengaruh signifikan terhadap manajemen laba pada perusahaan BUMN yang terdaftar di Bursa Efek Indonesia, sehingga H4 diterima kebenarannya.

e. Motivasi bonus, motivasi kontrak hutang, motivasi politik dan kualitas audit secara simultan berpengaruh signifikan terhadap manajemen laba pada perusahaan BUMN yang terdaftar di Bursa Efek Indonesia.

Untuk penelitian selanjutnya masih banyak variabel lain yang dapat mempengaruhi manajemen laba, seperti motivasi pajak dan corporate governance. Penelitian ini juga menggunakan Model Jones untuk mengukur manajemen laba akrual, masih banyak pengukuran lain yang dapat digunakan seperti manajemen laba riil atau manajemen laba akrual dengan model Khotari. Implikasi penelitian dapat dirasakan oleh pihak investor perusahaan, untuk lebih berhati-hati dalam mengambil keputusan investasi. 


\section{DAFTAR PUSTAKA}

Barus, Sembiring (2012). "Faktor-faktor yang mempengaruhi motivasi Manajemen laba di seputar right ISSUE, Volume 2, Nomor 01, April 2012

Christiani, Nughrahanti (2014). Pengaruh Kualitas Audit Terhadap Manajemen Laba, Jurnal Akuntansi dan Keuangan, Vol. 16, No. 1, Mei 2014, 52-62

Christiani, Ingrid dan Y.W. Nugrahanti, Pengaruh kualitas audit terhadap manajemen laba. Jurnal Akuntansi dan Keuangan, 16 (1), 2014, 52-62.

Hadidi, Sutrisno (2017). Pengaruh Motivasi, Struktur Kepemilikan, Kualitas Audit Terhadap Manajemen Laba, ISBN 978-602-70083-4-2

Ikhlas Arfan, dan Herkulanus Bambang Suprasto. 2008. Teori Akuntansi dan Riset Multiparadigma. Yogyakarta: Graha ilmu.

Jensen, M.C dan W.H. Meckling (1976). Theory of The Firm: Managerial Behaviour, Agency Cost, and Ownership Structure, Journal of Financial Economics, Vol. 3, No. 4, pp. 305360, www.ssm.com.

Kusumawardani Novia F., Rosiyana Dewi (2016), Motivasi bonus, pajak, dan utang dalam tindakan Manajemen laba (Studi Perusahaan Manufaktur yang Terdaftar di Bursa Efek Indonesia), Media Riset Akuntansi, Auditing \& Informasi Vol. 16 tahun 2016

Permatasari Kono, Yuyetta (2013), Pengaruh Arus Kas Bebas, Ukuran KAP, Spesialisasi Industri KAP, Audit Tenur dan Independensi Auditor terhadap Manajemen Laba, Volume 2, Nomor 3., Tahun 2013, Halaman 1 http://ejournals1.undip.ac.id/index.php/accounting ISSN (Online): 2337-3806

Rahmawati , Agustin Palupi (2017), Analisis faktor-faktor yang mempengaruhi manajemen laba, ISBN 978-602-70083-4-2

Scott. 2012. Financial Accounting Theory 6th. Pearson

Subramanyam, K.R., Financial statement analysis. Edisi 11. Mc Graw-Hill Education, 2014.

Sumarsan, Thomas. 2010. Sistem Pengendalian Manajemen (Konsep, Aplikasi dan PengukuranKinerja ). Jakarta: Indeks.

Undang-Undang Republik Indonesia Nomor 40 Tahun 2007 tentang Perseroan Terbatas.

Sulistiawan, Dedhy, Yeni Januarsi, dan Liza Alvia, Creative accounting. Penerbit Salemba Empat, 2011.

www.idx.com

www.idnfinancials.com 


\section{LAMPIRAN}

\section{Tabel 1. Statistik Deskriptif}

\begin{tabular}{|l|r|r|r|r|r|}
\hline & \multicolumn{1}{|c|}{ Descriptive Statistics } \\
\hline & \multicolumn{1}{|c|}{ Minimum } & Maximum & \multicolumn{1}{c|}{ Mean } & Std. Deviation \\
\hline Y = Manajemen Laba & 65 & .18 & 1012.90 & 77.9511 & 249.75181 \\
X1 = Motivasi Bonus & 65 & .00 & .28 & .0542 & .05679 \\
X2 = Motivasi Kontrak Utang & 65 & .00 & .92 & .5517 & .26869 \\
X3 = Motivasi Biaya Politik & 65 & 23.81 & 34.66 & 30.4280 & 2.68951 \\
X4 = Kualitas Audit & 65 & .00 & 1.00 & .5231 & .50335 \\
Valid N (listwise) & 65 & & & & \\
\hline
\end{tabular}

Tabel 2. Uji Multikolenieritas

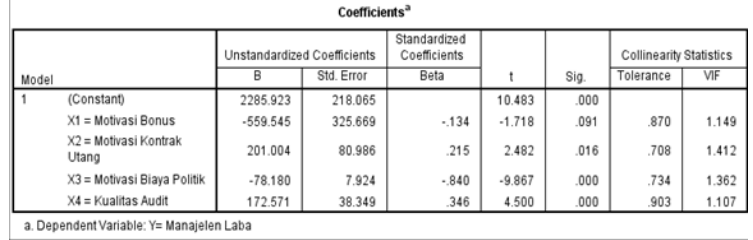

\section{Tabel 3. Uji Parsial (Uji t)}

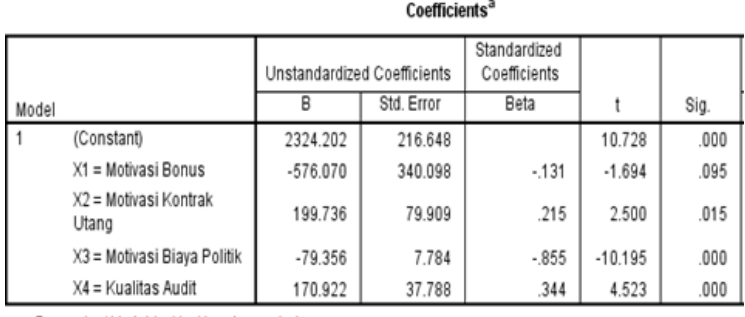

Tabel 4. Uji simultan (Uji F)

\begin{tabular}{|c|c|c|c|c|c|c|}
\hline Mode & & Sum of Sarre & $d f$ & Mean Scuare & $\mathrm{F}$ & $\sin$ \\
\hline \multirow[t]{3}{*}{1} & Regression & 2728548.860 & 4 & \multirow{3}{*}{$\begin{array}{r}682137.215 \\
21058.548\end{array}$} & \multirow[t]{3}{*}{32.392} & \multirow{3}{*}{.000} \\
\hline & Residual & 1263512.856 & 60 & & & \\
\hline & Total & 3992061.716 & 64 & & & \\
\hline
\end{tabular}

a. Dependent Variable: $Y=$ Manajemen Laba

b. Predictors: (Constant), X4 = Kualitas Audit, X2 = Motivasi Kontrak Utang, X1 = Motivasi Bonus, X3 = Motivasi Biaya Politik

\section{Tabel 5. Koefisien Determinasi}

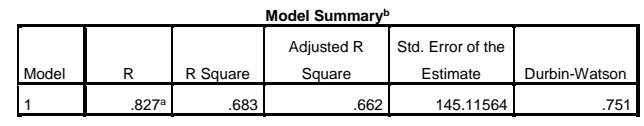

a. Predictors: (Constant), X4 = Kualitas Audit, X2 = Motivasi Kontrak Utang, X1 = Motivasi Bonus, $X 3=$ Motivasi Biaya Politik 
Nawang K, Titik P., Ayu SM. / Edunomika Vol. 03 No. 02 (Agustus 2019)

Gambar 1. Normal P-Plot of regression Standardized residual Normal P-P Plot of Regression Standardized Residual

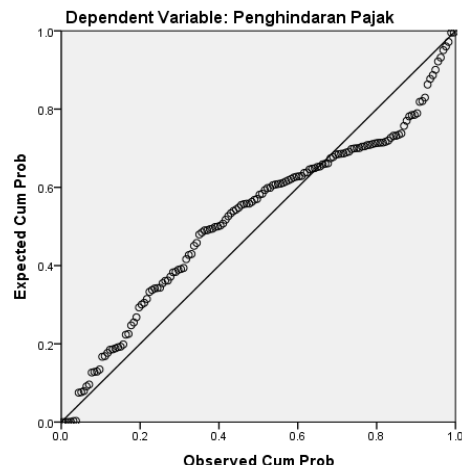

Gambar 2. Scatterplot

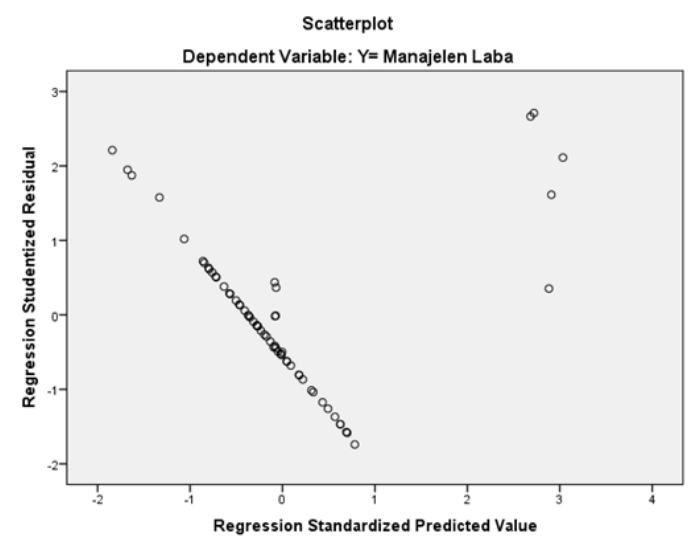

